\title{
MEASURING THE CHANGING GENEROSITY OF \\ UNEMPLOYMENT BENEFITS: BEYOND EXISTING INDICATORS
}

IE Working Paper
EC8-108-I

$11-04-2005$

Gayle Allard

Instituto de Empresa

Professor of Economic Environment, $\mathrm{PhD}$

María de Molina $12,5^{\mathrm{a}}$ planta

28006, España

gayle.allard@ie.edu

\begin{abstract}
:
There has long been a consensus that generous unem ployment benefits probably raise unem ployment rates. The link has been difficult to demonstrate, however, since existing indicators on the generosity o $\mathrm{f}$ unemployment benefits overlook key as pects of the system that $\mathrm{m}$ ay influence worker response. The au thor develops a new indicator fo $r$ unemployment benefits in 21 countries in the 1950-2003 time period which combines the amount of the subsidy with their tax treatm ent, their duration and the conditions that $m$ ust be m et in order to collect them . The new indicator shows that benefit genero sity has indeed risen over tim $\mathrm{e}$ and differs greatly among countries, opening up future directions for em pirical research.
\end{abstract}

\section{Keywords:}

unemployment benefits, eligibility conditions, labor $\mathrm{m}$ arket reform, unemployment 



\section{Introduction}

Every industrialized country has a schem e that provides the jobless with tem porary compensation for lost earnings, as long as they meet certain conditions. Most of these programs were put in place after World War II, with the purpose of providing income security for workers and their families. Since unemployment falls hardest on lower-income categories of workers, the programs are also intended to prom ote greater equality. ${ }^{i}$ And they also have an efficiency objective: to enable workers to take the tim e to find a better " $m$ atch" between their abilities and the needs of the job market, thus enhancing efficiency overall.

Unemployment benefits may, however, work agai nst these objectives and actually increase unemployment rates. If the benefits are high in relation to the expected $\mathrm{m}$ arket wage, they give workers incentives to remain jobless for longer periods, and boost the "reservation wage" at which they would be willing to reenter the job market. Many empirical studies find that the duration of unem ployment spells is linked to the level of benefits: in recent studies, the outflow rates from unemployment were found to increase considerably at around the time that unemployment benefits were exhausted in th e United States, Canada, Japan, France, Spain ii, Sweden ${ }^{\mathrm{iii}}$, the Netherlands ${ }^{\mathrm{iv}}$ and Germ any ${ }^{\mathrm{v}}$. Other studies have shown that the way that benefits are adm inistered -what the requirem ents are for job search or for reporting to officials - have a substantial effect on unem ployment duration. ${ }^{\text {vi }}$ This effect is more intense when benefits are com bined with other provisi ons for the jobless, such as child care or housing allowances, which are provided in many countries. ${ }^{\text {vii }}$

Since unemployment benefits provide an alternative to work, they generate wage pressures that spread throughout the economy. Unions may make stronger wage demands if they know that dismissed workers will be well provided for; and the higher "reservation wage" that results from the availability of non-work income also puts upward pressure on wages. ${ }^{\text {vii }}$ This is particularly true in countries where low-income groups face high average tax rates. ${ }^{\text {ix }}$ If unemployment insurance has a high budget cost , the governm ent may find it necessary to raise payroll or other taxes to finance the benefits. This will further boost labor costs and the impact on unem ployment will be intensif ied. ${ }^{\mathrm{x}}$ Generally, it is accepted that generous unemployment benefit systems raise unemployment rates. ${ }^{\text {xi }}$

Do unemployment benefits achieve their goal of promoting equity and efficiency? Som e economists argue that they are not effectivel y targeted at the poor and are "inherently inefficient and inequitable" as currently practiced in m ost countries. ${ }^{\text {xii }}$ There is also evidence that they may affect employment rates. The availability of benefits may raise joblessness, but it may also attract people into the work $\mathrm{f}$ orce so that they can eventually qualify for benefits. ${ }^{\text {xiii }}$ 


\section{Discussion: How Can the Generosity of Unemployment Benefits Be Measured?}

Most empirical studies that have attem pted to evaluate the im pact of benefit levels on employment, unemployment and equity have us ed the OECD's com prehensive indicator for gross replacement rates to represent the unem ployment benefit system. This complex index, first published in the 1994 Jobs Study, covers odd years in the 1961-1999 period and attem pts to summarize the level of gross unemployment benefit entitlements relative to gross earnings in each OECD country. To do this, it takes an unweighted average of 18 gross replacem ent rates which include three household types (singl e, dependent spouse and spouse in work) and three time periods (the first year, the second and third year, and the fourth and fifth years of unemployment), during which benefits typically va ry. It divides this figure by the average of two earnings levels: average earnings for a production worker and two-thirds of average earnings. ${ }^{\text {xiv }}$ The result is the $\mathrm{m}$ ost comprehensive indicator available for the $\mathrm{m}$ onetary generosity of unemployment benefits across countries and over time.

Despite its com plexity, however, the OECD i ndicator overlooks several key features of unemployment benefits that could conceivably have a large im pact on the net reservation wage. One of these is taxes. Different tax treatm ent of wages and unemployment benefits might alter the replacem ent rate and have an im pact on workers' decisions whether or not to work. OECD countries differ widely in th eir taxation of unem ployment benefits: in Australia, Austria, Germany, Japan, New Zeala nd and Portugal, for instance, unem ployment insurance benefits are not subject to incom e tax, while in other countries they are taxed, at different rates. ${ }^{\mathrm{xv}}$ Tax treatment has also varied in given countries over the postwar period. So far the OECD has developed no "net replacem ent rate" that covers as long a tim e span as its gross replacement rate: the available data, based on its tax-benefit $\mathrm{m}$ odels, are only for selected years. ${ }^{\mathrm{xvi}}$

Another important feature of unemployment benefit systems that may condition workers' jobmarket decisions is the duration of benefits. OECD countries vary widely in the am ount of time that unemployment benefits are paid out to the jobless (and before they qualify for social assistance schemes, which are m eans-tested in many countries). In 1999 they could be collected for periods as short as six months in some countries (e.g., Italy, the United Kingdom and the United States) and as long as $60 \mathrm{~m}$ onths in others (Denm ark, France, the Netherlands). ${ }^{\text {xvii }}$ These different tim e periods, com bined with identical replacem ent rates, could conceivably have dramatically different effects on the behavior of the unem ployed. In fact, some studies have found th at outflow rates from unemployment increased considerably at around the tim e that unem ployment benefits were exhausted in several countries; and whether or not an individual would continue to receive benefits was found to be the key factor in exit rates from unemployment in the Spanish and Portuguese cases. ${ }^{\text {xviii }}$

Possibly the most important factor influencing the decisions of the unemployed, and the most difficult to quantify, is how onerous it is to qualify for and collect unem ployment benefits. Again, countries vary enorm ously in both the eligibility conditions they im pose for the unemployed to qualify for benefits, and the strictness with which these conditions are enforced. In countries like Switzerland and the United States, for exam ple, the jobless must present evidence of job search on a weekly basis, while in other countries like Spain, the 
unemployed need only display an identity document at a governm ent employment office every three $m$ onths to continue receiving bene fits. These conditions have also changed considerably over time in the countries in th is study. For instance, the unem ployed in the immediate postwar period typically lost their be nefits if they ref used a suitable job of fer, while by the 1980s they could refuse a job offer and continue collecting unem ployment insurance after a brief "sanction" period during which benefits were suspended (typically one to several weeks). These changing conditi ons may have had a large influence on the decisions of the jobless on whether or not to look for work.

Many economists believe that the eligibility cond itions for collecting benefits - the definition of loss of work and availability for work, valid reasons for quitting, the definition of suitable work, and requirem ents to actively seek work ${ }^{\text {xix }}$ are a key policy tool for $\mathrm{m}$ anaging the unemployment problem. The reasoning behind this argument is simple. Whereas with the replacement rate (gross or net) or the duration issue, the jobless are pondering a decision over collecting more or less $\mathrm{m}$ oney, strict eligibility criteria can ef fectively reduce a given replacement rate to zero. In fact, som e economists believe that well designed and enforced eligibility criteria can not only of fset the disincentive effects of unemployment benefits, but they can reduce the unem ployment rate to less than the natural rate. This is their line of reasoning:

The behavior that is supposed to be induced by eligibility criteria-such as being ready to start work at short notice- should dir ectly increase the chance of finding work. The criteria also imply a disutility effect, which encourages a more intense search for work, and an "entry" ef fect: if the requirements are onerous (and hence the disutility effect is suf ficiently large), som e people will drop their benef it claim rather than comply. Benefits can actually be $\mathrm{m}$ ade conditional upon an intensity of job search higher than the individual would undertake in the absence of a benefit entitlem ent; hence benefit systems can be designed to generate unemployment levels below those arising under laissez faire (in the absence of a benefit system). ${ }^{\mathrm{xx}}$

One study of four European countries that ach ieved success in labor markets found that much stricter enforcement of job search and suitable work provisions had been a key elem ent in all of their reform programs. ${ }^{\mathrm{xxi}}$

It appears, then, that any study attem pting to evaluate the im pact of the unem ployment insurance system on labor markets must include its eligibility features. This aspect, however, is so dif ficult to quantify that it has been om itted from nearly all studies. Like the EPL indicator, it would require a thorough country- by-country, year-by-year review of labor legislation, and even such an exhaustive revi ew would leave out the enforcem ent factor discussed in relation with EPL above.

Some attempts have been m ade to quantify on a piecemeal basis the strictness of eligibility criteria. One exam ple is a study by the Danish Ministry of Finance, which constructed in 1997 an index for the strictness of eligibility requirements, occupational and geographical

criteria based on independent job search mobility criteria $f$ or suitable work, and the 
standard duration of benefit sanctions following vol untary quits and refusals of job offers. It evaluated the situation in 19 OECD countries in eight areas:

1. demands on job search activity,

2. demands on job availability when participating in active labor-m arket programs,

3. demands on occupational mobility,

4. demands on geographical mobility,

5. extent of valid reasons for refusal of $j$ ob offers or participation in active labormarket programs,

6. sanctions applied for self-induced resignation from a job,

7. sanctions applied for refusal of a job offer or active labor-m arket programs, and

8. sanctions applied for repeated refusal of the above.

A survey was sent to participating countries, which reported what the legal situation was in each of these areas, and also gave an idea of how strictly existing rules were actually enforced in their countries. The answers were scored, as with the OECD's EPL indicator above, and a weighted average was taken that $\mathrm{m}$ ade it possible to rank countries by the strictness of their eligibility criteria. ${ }^{\text {xii }}$

The Danish survey gave researchers a fairly comprehensive cross-country indicator for a single year. The indicator has the sam e weaknesses as the EPL indicator discussed above. Legislation can often be obscure and difficult to interpret; variations in enf orcement may be very large; and the $f$ inal score is sensitive to th e weighting system that is applied. $W$ ith its weaknesses, however, it does give a good picture of differences across countries in eligibility criteria.

Since this study aimed to evaluate the im pact on employment and unemployment rates of all of the $\mathrm{m}$ ajor labor-market policies and ins titutions, it required a good indicator for the unemployment benefit system. To portray as co mpletely as possible the disincentive ef fects of the unem ployment insurance system, it had to incorporate all of the features discussed above: income levels of recipients, duration of benefits, taxes and the eligibility criteria. Since no such indicator existed, developing a time series that would approxim ate a "net reservation wage" became another key pursuit of the study.

The logical starting point was the OECD's gross replacem ent rate tim e series, which was converted roughly into a net replacem ent rate by using a ratio of net to gross replacem ent rates given by the OECD in an appendix to its 1997 Jobs Study. ${ }^{\text {xxiii }}$ This ratio estim ates the effect on the replacement rate of personal incom e taxes and social security paym ents applied to unemployment benefits in four different time periods. ${ }^{\text {xxiv }}$

Incorporating the duration of unem ployment benefits into the sam e indicator was $\mathrm{m}$ ore difficult. Although data could be obtained on the frequent changes in the $m$ aximum duration of benefits from journals and national legislation, simply multiplying the net replacement rate by the num ber of years that benefits could be collected produced differences in the final 
figures that appeared to be too large to reflect the real incom e options faced by the jobless. Since in fact an unem ployed person is more likely to be making a job-search decision on the basis of the incom e he/she expects to receive from the benefit system over the next few months, it was decided to reflect different duration periods only up to one year. Thus the net replacement rate was $m$ ultiplied by some number between 0 and 1: 0 if no benefits were available (which was the case in som e OECD countries in the im mediate postwar period), some intermediate number if they were availa ble for a fraction of a year (e.g., $6 \mathrm{~m}$ onths $=$ 0.5 ), and 1 if they were available for a full y ear or longer. By the end of the period under study, this meant that most countries, even thos e where benefits were practically indefinite, were assigned a $1 .^{\mathrm{xxv}}$

Finally, a way had to be found to incorporate the strictness of eligibility criteria into the indicator. ${ }^{\text {xxvi }}$ Since these criteria can be seen as determ ining the probability of collecting benefits, the scheme developed by the Danish Finance Ministry was adapted and converted into an average probability of collecting unem ployment benefits, based on the strictness of eligibility criteria.

The Danish questionnaire was taken as a starti ng point, with some questions omitted because information was very dif ficult to obtain from a review of legislation and the literature. The scores used by the Danish researchers were converted into probabilities and the weightings were changed som ewhat, leaving the questionna ire and its scores as follows (the full questionnaire is given in Appendix 1):

\section{$<$ Insert Table 1 here $>$}

Items 1 through 5 were assigned a weight of one, item 6 a weight of 0.75 , and item 7 a weight of 0.25 in the final indicator. The resulting num ber was divided by six (the sum of all the weights) to give a (weighted) average probability of qualifying for unemployment benefits.

This probability was then $\mathrm{m}$ ultiplied by the other $\mathrm{f}$ eatures of the unem ployment benefit system described above, to yield a single num ber that would reflect the global generosity of the unemployment benefit system and its incentive or disincentive effects on the jobless. In other words, the final indicator consists of all four features discussed above, as follows:

Net reservation wage $(\mathrm{NRW})=$ gross repl acement rate * (ratio net RR/gross RR) * duration * probability of collecting benefit

where duration and probability are both some number between 0 and 1.

The result, again, is far from being a perf ect indicator. Legislative inform ation on unemployment benefit systems was difficult to obtain, and there were gaps after an exhaustive review of labor law for 21 countries and 50 years, using the same sources given above. These gaps could only partially be filled in from discussions in the specialized literature, and $\mathrm{m}$ uch guesswork was necessary to construct an indi cator spanning the entire postwar period. In 
countries like the United States, Canada or Au stralia, where no Federal law exists setting out guidelines for the unemployment insurance system and definition and administration is left up to the individual states xxvii, information could only be taken $\mathrm{f}$ rom the literature. ${ }^{\mathrm{xxviii}}$ Enforcement, of course, was also omitted, as were many other aspects of benefit systems.

One highly relevant feature that had to be om itted due to the com plexity of the schemes and the difficulty of obtaining hom ogeneous information was the housing and other benefits that are available to the unem ployed in m any OECD countries. In the United Kingdom , the generous housing benefits given to the unem ployed may play a key role in job $\mathrm{m}$ arket decisions. In fact, the United Kingdom 's replacement rate as reported in the OECD indicator is one of the OECD's lowest, but experts say that housing and other benefits may make it one of the highest. ${ }^{\text {xxix }}$ One study conducted by the Dutch Cent raal Planbureau in 1995 com pared the OECD's estimates of replacement rates with a much broader definition of income support to the unemployed that included child support, supplementary social assistance and housing benefits, and additionally estim ated the impact of relevant tax on benefits. For the United Kingdom, this study estim ated a replacem ent rate of either $69.8 \%$ or $41.4 \%{ }^{\mathrm{xxx}}$ in 1993 , compared to an OECD figure of $18.5 \%$ in the same year. Differences for other countries were less dramatic, but all of the replacem ent rates calculated by the CPB were higher than those obtained by the OECD. ${ }^{\text {xxi }}$

Another important omission resulted from the decision to use in the indicator only the income available under unemployment insurance schemes. Nearly all countries have supplem entary income assistance which can be collected on ce unemployment benefits run out and which may extend by months or even years the time that an individual can remain unemployed while collecting benefits. (These supplem entary sources of income were included in the estim ates by the Dutch Centraal Planbureau, cited above.) xxxii There are countries like Italy where supplementary schemes are the $m$ ain form of unem ployment insurance, and where the OECD's replacement rates seriously understate the income that the unemployed can expect to receive. Although Italy's replacem ent rates are the OECD's lowest, most jobless during the postwar period have received benefits from alternate support system s like the the Cassa de Integrazione Guadagni Straordinaria (CIG S), which started as a system providing compensation for short-time working in a lim ited range of industries and was extended in 1947 to cover tem porary lay-offs. It has gradually become a shadow unem ployment compensation scheme which offers benefits that are often indefinite and $\mathrm{m}$ uch higher than those available under the official unemployment scheme. ${ }^{\text {xxxiii }}$ 


\section{Conclusion: New Indicator Shows How Benefit Generosity Has Risen}

Despite its om issions and weaknesses, the rela tively complex indicator developed for this study offers some surprising contrasts with the gross replacement rate as a reflection of the generosity of countries' unem ployment insurance systems. Unem ployment benefits understood in their fullest sense, as the compendium of incentives offered to the jobless, grew steadily more generous from the 1960s onward in m ost countries, with particularly large increases coinciding with periods of high unem ployment. They were trim med in various countries in the 1990s in an effort to reduce th e incentives to remain jobless. This trim ming often took the form of stricter conditions to collect the benefit. This effect had escaped earlier studies but is f aithfully reproduced here, by a falling average probability of being able to collect benefits.

The indicator also shows a relatively sharp cont rast between benefit generosity in European and non-European countries, and between non-English-speaking and English-speaking countries. In general, unem ployment benefits are higher and easier to collect in the form er than in the latter, as Charts 1 and 2 below show. 
<Insert Chart 1 here>

<Insert Chart 2 here $>$ 
Tables and Figures

Table 1: Unemployment benefit eligibility questionnaire

\begin{tabular}{|l|l|}
\hline Question & Score assigned to answer \\
\hline $\begin{array}{l}\text { 1. Demands on job search } \\
\text { activity }\end{array}$ & $\begin{array}{l}.75=\text { no systematic check; } .5=\text { unem ployed must regularly prove job } \\
\text { search activity; } .25=\text { the unem ployed must often, i.e., every week or } \\
\text { every second week, prove job search activity }\end{array}$ \\
\hline $\begin{array}{l}\text { 2. Demands on } \\
\text { occupational mobility }\end{array}$ & $\begin{array}{l}.9=\text { the unemployed can refuse job offers in other occupational areas } \\
\text { for } 6 \text { months or more; } .7=\text { can refuse for less than } 6 \text { m onth; } .5=\text { no } \\
\text { explicit reservations, but the unem ployed's qualifications and the } \\
\text { length of the unem ployment spell are taken into account; } .25=\text { no } \\
\text { reservation, meaning the unem ployed must accept all jobs he is } \\
\text { capable of doing }\end{array}$ \\
\hline $\begin{array}{l}\text { 3. Demands on } \\
\text { geographical mobility }\end{array}$ & $\begin{array}{l}.9=\text { no demands; } .7=\text { must accept daily transportation time of less than } \\
2 \text { hours per day; } .5=\text { must accept transport time of } 2-3 \text { hours; } .3=\text { must } \\
\text { accept transport of 3-4 hours or more; } .1=\text { must be willing to move }\end{array}$ \\
\hline $\begin{array}{l}\text { 4. Extent of valid reasons } \\
\text { for refusal of job offers or } \\
\text { ALMPs }\end{array}$ & $\begin{array}{l}.75=\text { relatively large number of valid reasons for refusal; } .5=\text { average } \\
\text { amount of restrictions; } .25=\text { relatively few valid reasons for refusal }\end{array}$ \\
\hline $\begin{array}{l}\text { 5. Sanctions applied for } \\
\text { refusal of job offer or } \\
\text { ALMP }\end{array}$ & $\begin{array}{l}.9=0-4 \text { weeks; } .7=5-9 \text { weeks; } .5=10-14 \text { weeks; } .3=\text { m ore than } 14 \\
\text { weeks; .1=suspension of unemployment benefit }\end{array}$ \\
\hline $\begin{array}{l}\text { 6. Sanctions applied for } \\
\text { repeated refusal of job } \\
\text { offer or ALMP }\end{array}$ & $\begin{array}{l}.9=\text { no further sanctions in case of repeated rejections; } .7=\text { sanctions } \\
\text { are more rigorous after third rejection; } .5=\text { sanctions are m } \\
\text { rigorous after second rejection and unem } \\
\text { entitlement to benef its; } .3=\text { suspension of unemployment benefits } \\
\text { after second rejection; } .1=\text { benefit has already been suspended after } \\
\text { first rejection }\end{array}$ \\
\hline $\begin{array}{l}\text { 7. Sanctions applied for } \\
\text { self-induced resignation } \\
\text { from job }\end{array}$ & $\begin{array}{l}.9=0-4 \text { weeks; } .7=5-9 \text { weeks; } .5=10-14 \text { weeks; } .3=m \text { ore than } 14 \\
\text { weeks; .1=suspension of unemployment benefit }\end{array}$ \\
\hline
\end{tabular}


Chart 1: Different measures of unemployment benefit generosity in selected countries and OECD (unweighted average), 1960-2003

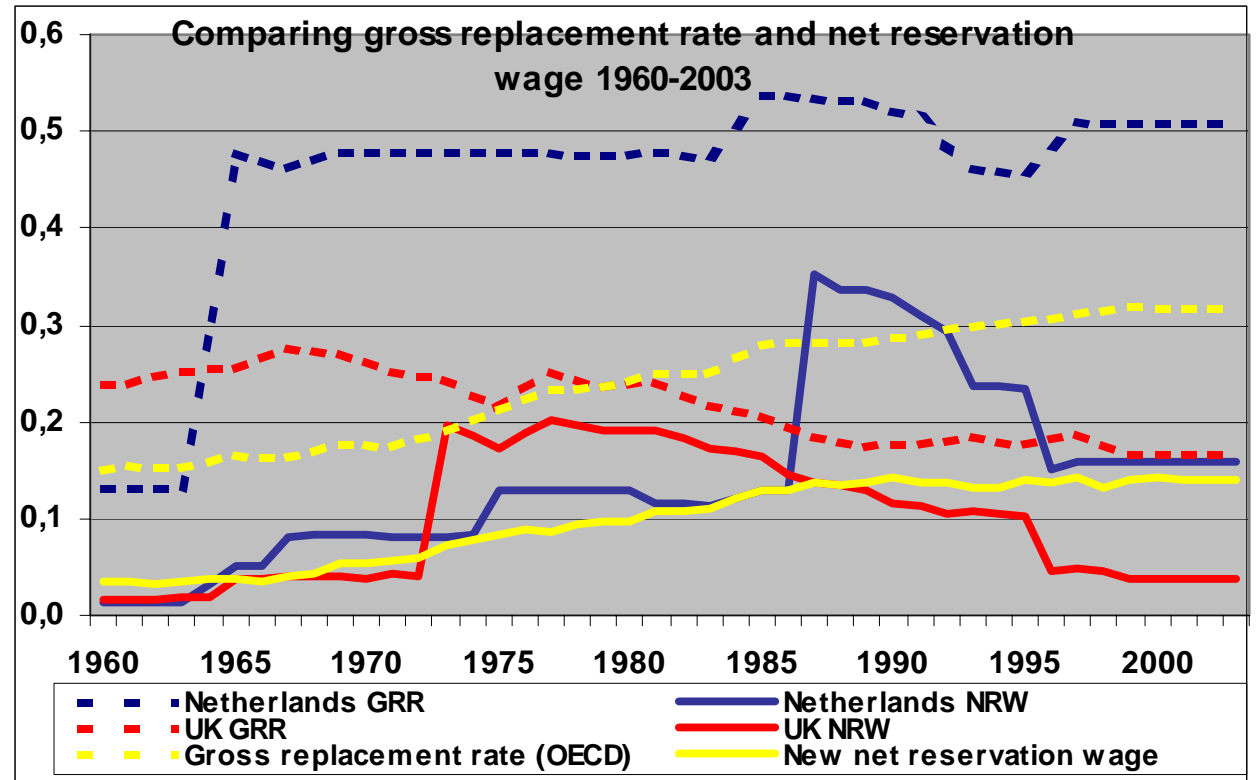

Chart 2: Various estimates of unemployment benefit generosity

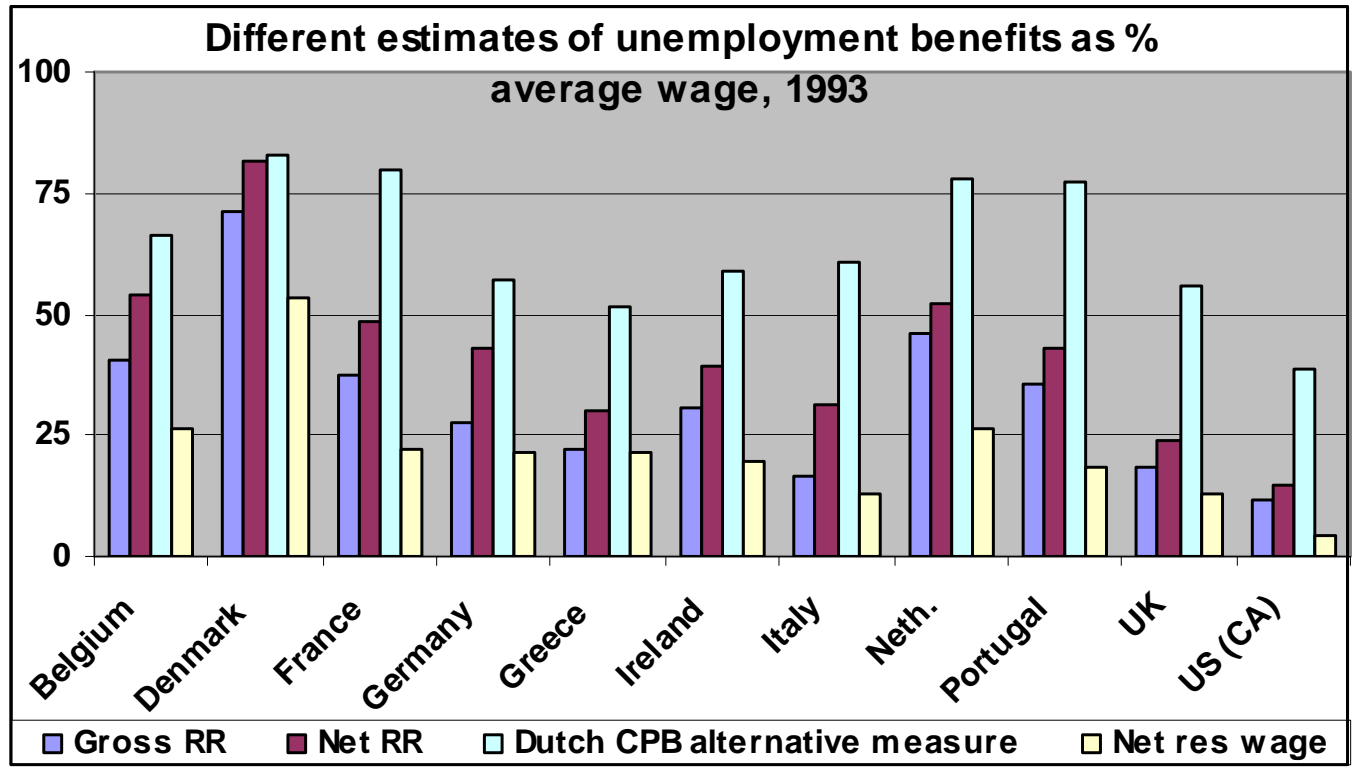




\section{Appendix 1: The Questionnaire for Benefit Eligibility}

The questionnaire below lists (in bold face) the specific questions that were asked regarding each law approved during the period in the countries surveyed, to evaluate the relevant aspects of eligibility for unemployment benefits. The scores assigned for each possible answer (which are an attempt to reflect the probability of being eligible to collect benefits) are given in plain type below the question. 
Name of Law

Number

Date

\section{ELIGIBILITY FOR UNEMPLOYMENT BENEFIT}

Is the unemployed person required to demonstrate that

he/she is actively seeking work in order to collect

unemployment benefits?

$0.75=$ no systematic check

$0.5=$ the unemployed must regularly prove job search activity

$.25=$ the unemployed must often, i.e., every week or every second week, prove job search activity

Is the unemployed person required to accept a job that is

offered which is outside the occupational area that he/she

is trained for or has worked in?

$0.9=$ the unemployed can refuse job offers in other occupational areas

for 6 months or more

$0.7=$ the unemployed can refuse job offers in other occupational areas

for less than 6 months

$0.5=$ there are no explicit reservations, but the unemployed's qualifications

and length of the unemployment spell are taken into account

$0.25=$ no reservation, meaning the unemployed must accept any job offered

that he is capable of doing

Is the unemployed person required to move to a different

geographical area if a job is offered to him/her there?

$0.9=$ no demands

$0.7=$ must accept daily transportation time of less than 2 hours per day

$0.5=$ must accept transport time of 2-3 hours

$0.3=$ must accept transport of 3-4 hours or more

$0.1=$ must be willing to move

What acceptable reasons can be given for refusing a job

offer or a training program while collecting benefits?

$0.75=$ relatively large number of valid reasons for refusal

$0.5=$ average amount of restrictions

$0.25=$ relatively few valid reasons for refusal

If a person leaves a job voluntarily, what sanctions are applied?

$0.9=0-4$ weeks without unemployment benefit

$0.7=5-9$ weeks without unemployment benefit

$0.5=10-14$ weeks without unemployment benefit

$0.3=$ more than 14 weeks without unemployment benefit

$0.1=$ total suspension of unemployment benefit

If a person refuses a job offer or refuses to participate in a training program while collecting benefits, what sanctions are applied?

$0.9=0-4$ weeks without unemployment benefit

$0.7=5-9$ weeks without unemployment benefit

$0.5=10-14$ weeks without unemployment benefit

$0.3=$ more than 14 weeks without unemployment benefit 
$0.1=$ total suspension of unemployment benefit

If a person repeatedly refuses job offers or training programs while collecting benefits, what sanctions are applied?

$0.9=$ no further sanctions in cases of repeated rejections

$0.7=$ sanctions are more vigorous after third rejection

$0.5=$ sanctions are more vigorous after second rejection and unemployed could lose entitlement to benefits

$0.3=$ suspension of unemployment benefits after second rejection

$0.1=$ benefit has already been suspended after first rejection

What is the maximum period during which unemployment

benefits can be collected (as a fraction of one year)?

How long must a person work in order to be able to collect

unemployment benefits (number of weeks)? 
Appendix 2: Unemployment Benefit Indicator ("Net Reservation Wage") for 21 OECD Countries, 1950-2003

\begin{tabular}{|c|c|c|c|c|c|c|c|c|c|c|c|c|c|c|c|c|c|c|c|c|c|}
\hline & AUS & AUT & BEL & CAN & DEN & FIN & FRA & GER & GRE & IRE & IT & JAP & NTL & $\mathbf{N Z}$ & NOR & POR & SP & SWE & SWI & UK & $\mathbf{U S}$ \\
\hline 1960 & 1.5 & 6.9 & 20.7 & 6.4 & 0.0 & 0.2 & 7.6 & 4.4 & 1.5 & 4.0 & 1.1 & 0.9 & 1.4 & 11.6 & 0.3 & 0.0 & 0.0 & 1.3 & 0.0 & 1.7 & 0.7 \\
\hline 1960 & 1.5 & 6.9 & 20.7 & 6.4 & 0.0 & 0.2 & 7.6 & 4.4 & 1.5 & 4.0 & 0.8 & 0.9 & 1.4 & 11.6 & 0.3 & 0.0 & 1.0 & 1.3 & 0.0 & 1.7 & 0.7 \\
\hline 1962 & 1.7 & 6.6 & 18.9 & 6.4 & 0.0 & 0.2 & 7.6 & 4.5 & 1.5 & 4.1 & 0.7 & 0.9 & 1.4 & 11.0 & 0.3 & 0.0 & 1.0 & 1.2 & 0.0 & 1.7 & 0.8 \\
\hline 1963 & 1.8 & 6.3 & 18.3 & 6.4 & 0.0 & 1.9 & 7.7 & 4.5 & 1.5 & 4.1 & 0.6 & 0.9 & 1.4 & 10.4 & 0.2 & 0.0 & 2.0 & 1.1 & 0.0 & 1.8 & 1.0 \\
\hline 1964 & 1.7 & 5.9 & 17.1 & 6.2 & 0.0 & 1.8 & 7.7 & 4.5 & 1.5 & 4.1 & 0.6 & 0.9 & 3.3 & 14.6 & 0.2 & 0.0 & 3.0 & 1.4 & 0.0 & 1.8 & 0.9 \\
\hline 1965 & 1.6 & 5.6 & 15.8 & 6.1 & 0.0 & 1.6 & 7.7 & 4.5 & 1.5 & 4.2 & 0.5 & 0.9 & 5.2 & 13.6 & 0.2 & 0.0 & 4.1 & 1.6 & 0.0 & 3.7 & 0.9 \\
\hline 1966 & 1.5 & 5.1 & 13.1 & 5.9 & 0.0 & 1.5 & 7.6 & 4.4 & 1.5 & 4.2 & 0.5 & 0.9 & 5.1 & 13.5 & 0.2 & 0.0 & 4.1 & 1.6 & 0.0 & 3.8 & 0.9 \\
\hline 1967 & 1.4 & 4.6 & 12.5 & 5.8 & 6.7 & 1.4 & 7.5 & 4.4 & 1.5 & 3.6 & 0.6 & 0.9 & 8.1 & 13.5 & 0.2 & 0.0 & 4.1 & 1.6 & 0.0 & 4.0 & 0.9 \\
\hline 1968 & 1.3 & 6.1 & 14.8 & 6.2 & 7.5 & 1.8 & 8.0 & 4.4 & 1.5 & 3.5 & 0.5 & 0.9 & 8.2 & 13.4 & 0.2 & 0.0 & 4.1 & 1.9 & 0.0 & 4.0 & 0.9 \\
\hline 1969 & 1.2 & 7.5 & 17.0 & 6.6 & 8.3 & 2.2 & 8.4 & 22.8 & 1.5 & 3.3 & 0.5 & 0.9 & 8.4 & 13.3 & 0.2 & 0.0 & 4.1 & 2.1 & 0.0 & 3.9 & 0.9 \\
\hline 1970 & 1.2 & 7.8 & 17.1 & 6.4 & 8.1 & 2.6 & 7.9 & 22.5 & 1.5 & 3.4 & 0.4 & 0.9 & 8.4 & 12.1 & 0.3 & 0.0 & 3.4 & 2.1 & 0.0 & 3.8 & 1.0 \\
\hline 1971 & 1.4 & 9.1 & 18.4 & 10.4 & 9.6 & 1.6 & 7.6 & 23.9 & 1.5 & 4.2 & 0.4 & 1.1 & 8.1 & 12.1 & 0.3 & 0.0 & 2.7 & 2.3 & 0.0 & 4.2 & 1.1 \\
\hline 1972 & 1.5 & 8.7 & 19.6 & 12.4 & 9.7 & 3.8 & 7.4 & 23.6 & 1.5 & 4.0 & 0.4 & 1.1 & 8.1 & 12.3 & 0.4 & 0.0 & 2.7 & 2.5 & 0.0 & 4.1 & 1.1 \\
\hline 1973 & 1.6 & 14.8 & 20.7 & 14.5 & 9.9 & 5.9 & 7.1 & 23.2 & 1.5 & 5.0 & 0.3 & 1.1 & 8.1 & 12.6 & 0.7 & 0.0 & 2.7 & 4.5 & 0.0 & 19.6 & 1.1 \\
\hline 1974 & 1.9 & 14.9 & 21.0 & 14.2 & 10.4 & 5.5 & 7.7 & 23.6 & 1.5 & 5.9 & 0.4 & 7.5 & 8.5 & 12.7 & 0.7 & 0.0 & 3.7 & 5.8 & 0.0 & 18.4 & 1.7 \\
\hline 1975 & 2.0 & 15.0 & 21.4 & 13.9 & 10.8 & 5.1 & 8.3 & 23.9 & 1.5 & 6.7 & 0.5 & 7.5 & 12.9 & 12.8 & 0.7 & 0.5 & 4.6 & 8.7 & 0.0 & 17.3 & 1.7 \\
\hline 1976 & 2.2 & 16.5 & 21.3 & 13.7 & 11.5 & 5.6 & 8.0 & 24.0 & 1.5 & 7.6 & 0.4 & 6.2 & 12.9 & 12.5 & 1.2 & 0.5 & 6.4 & 9.0 & 0.0 & 18.8 & 2.0 \\
\hline 1977 & 2.3 & 10.5 & 21.1 & 13.5 & 12.6 & 6.2 & 7.7 & 24.1 & 1.5 & 8.5 & 0.3 & 4.8 & 12.9 & 12.2 & 3.6 & 0.5 & 5.4 & 9.4 & 0.8 & 20.3 & 2.2 \\
\hline 1978 & 13.1 & 11.3 & 21.0 & 13.0 & 13.4 & 5.9 & 7.7 & 24.4 & 1.5 & 8.7 & 0.3 & 4.8 & 12.9 & 12.2 & 3.6 & 0.6 & 5.4 & 16.7 & 1.1 & 19.7 & 2.6 \\
\hline 1979 & 13.2 & 12.1 & 20.9 & 12.6 & 16.4 & 5.6 & 6.5 & 24.7 & 1.5 & 8.9 & 0.2 & 4.9 & 12.8 & 12.2 & 3.5 & 0.8 & 5.4 & 17.2 & 1.4 & 19.1 & 2.3 \\
\hline 1980 & 12.5 & 12.1 & 20.5 & 12.5 & 17.2 & 5.3 & 7.5 & 24.5 & 1.5 & 8.9 & 0.2 & 4.9 & 12.9 & 12.7 & 4.3 & 0.8 & 7.0 & 17.2 & 1.4 & 19.2 & 2.5 \\
\hline 1981 & 12.3 & 12.8 & 30.8 & 11.6 & 17.7 & 5.1 & 15.2 & 25.8 & 1.6 & 9.8 & 0.3 & 5.1 & 11.5 & 13.5 & 3.9 & 0.9 & 9.4 & 17.2 & 1.3 & 19.2 & 2.4 \\
\hline 1982 & 12.3 & 11.8 & 30.5 & 12.5 & 18.1 & 5.3 & 15.0 & 25.6 & 1.6 & 10.5 & 0.3 & 5.0 & 11.5 & 14.0 & 3.9 & 0.8 & 9.4 & 18.2 & 2.0 & 18.2 & 2.3 \\
\hline 1983 & 12.4 & 10.8 & 30.1 & 13.5 & 18.4 & 5.4 & 14.8 & 25.4 & 1.6 & 11.2 & 0.2 & 5.0 & 11.4 & 14.6 & 3.9 & 0.7 & 9.4 & 19.2 & 1.2 & 17.3 & 2.3 \\
\hline 1984 & 12.7 & 11.8 & 30.0 & 13.5 & 17.9 & 19.2 & 15.7 & 25.0 & 1.6 & 10.5 & 0.2 & 5.5 & 12.2 & 14.6 & 4.6 & 1.5 & 11.3 & 19.2 & 6.5 & 16.9 & 2.3 \\
\hline 1985 & 13.1 & 12.8 & 29.8 & 13.5 & 34.1 & 18.4 & 16.7 & 24.7 & 1.6 & 19.7 & 0.2 & 5.9 & 13.0 & 14.6 & 5.3 & 2.2 & 16.3 & 16.0 & 8.3 & 16.5 & 2.4 \\
\hline 1986 & 13.4 & 12.6 & 29.6 & 13.5 & 32.9 & 18.8 & 17.4 & 24.4 & 1.9 & 20.2 & 0.2 & 5.9 & 12.9 & 14.9 & 5.3 & 2.7 & 16.2 & 16.4 & 8.3 & 14.5 & 2.1 \\
\hline 1987 & 14.7 & 12.4 & 29.4 & 13.5 & 31.7 & 17.4 & 18.2 & 24.1 & 2.2 & 20.7 & 0.1 & 5.9 & 35.1 & 15.1 & 5.3 & 3.1 & 16.1 & 16.8 & 8.3 & 13.7 & 1.8 \\
\hline 1988 & 14.7 & 12.0 & 27.3 & 13.6 & 32.4 & 16.9 & 18.0 & 24.2 & 0.0 & 19.7 & 0.6 & 5.8 & 33.6 & 15.0 & 5.3 & 3.2 & 16.1 & 16.7 & 8.3 & 13.4 & 1.9 \\
\hline 1989 & 13.7 & 12.1 & 27.2 & 13.5 & 34.8 & 16.4 & 17.9 & 24.2 & 2.2 & 18.7 & 1.2 & 5.7 & 33.5 & 14.9 & 5.3 & 8.7 & 16.1 & 16.5 & 8.3 & 13.0 & 1.9 \\
\hline 1990 & 13.1 & 12.5 & 27.0 & 13.3 & 34.9 & 17.6 & 18.0 & 24.8 & 7.6 & 19.6 & 1.1 & 5.7 & 32.9 & 14.5 & 5.3 & 9.0 & 16.0 & 16.6 & 9.9 & 11.7 & 1.8 \\
\hline 1991 & 12.6 & 11.5 & 10.9 & 13.0 & 34.7 & 18.8 & 19.6 & 26.1 & 9.8 & 21.4 & 0.8 & 5.8 & 31.0 & 13.6 & 5.2 & 10.1 & 16.2 & 16.5 & 9.3 & 11.2 & 1.6 \\
\hline 1992 & 12.8 & 10.7 & 10.7 & 11.6 & 34.7 & 18.8 & 19.6 & 25.7 & 11.2 & 21.9 & 3.1 & 5.8 & 29.4 & 13.5 & 5.2 & 10.3 & 15.7 & 16.3 & 10.9 & 10.6 & 1.6 \\
\hline 1993 & 12.9 & 8.0 & 10.6 & 11.5 & 34.7 & 18.8 & 19.6 & 20.9 & 12.7 & 22.5 & 5.3 & 5.8 & 23.7 & 13.3 & 5.2 & 10.4 & 15.3 & 16.0 & 13.1 & 10.8 & 1.7 \\
\hline 1994 & 11.2 & 7.9 & 10.3 & 11.4 & 37.4 & 19.8 & 19.5 & 20.5 & 12.7 & 20.8 & 5.7 & 5.9 & 23.6 & 12.7 & 5.2 & 10.4 & 16.7 & 15.7 & 13.1 & 10.6 & 1.1 \\
\hline 1995 & 11.2 & 7.8 & 10.1 & 11.3 & 42.1 & 20.9 & 19.5 & 20.0 & 12.7 & 19.2 & 6.1 & 6.0 & 23.5 & 12.1 & 5.2 & 10.4 & 16.7 & 15.3 & 13.1 & 10.3 & 1.1 \\
\hline 1996 & 10.8 & 8.5 & 10.3 & 16.0 & 41.9 & 19.9 & 19.1 & 20.9 & 11.8 & 20.6 & 5.9 & 6.1 & 15.0 & 13.2 & 5.2 & 11.0 & 16.7 & 15.4 & 12.9 & 4.7 & 1.2 \\
\hline 1997 & 10.3 & 9.3 & 10.4 & 16.8 & 41.2 & 18.9 & 18.7 & 22.2 & 10.9 & 22.5 & 5.7 & 6.2 & 15.8 & 14.2 & 16.3 & 11.5 & 16.7 & 15.5 & 11.5 & 4.8 & 1.3 \\
\hline 1998 & 10.3 & 10.0 & 10.3 & 16.8 & 40.4 & 19.1 & 19.0 & 22.7 & 10.8 & 22.1 & 6.0 & 6.7 & 15.8 & 12.5 & 16.6 & 12.3 & 16.5 & 15.0 & 13.2 & 4.5 & 1.3 \\
\hline 1999 & 10.3 & 10.3 & 10.2 & 16.8 & 40.1 & 19.2 & 19.2 & 23.2 & 10.7 & 21.8 & 6.4 & 7.2 & 15.8 & 12.0 & 16.9 & 13.1 & 16.2 & 14.4 & 14.8 & 3.8 & 1.3 \\
\hline 2000 & 10.3 & 10.3 & 10.2 & 16.8 & 40.1 & 19.2 & 19.2 & 23.2 & 10.7 & 17.5 & 6.4 & 7.2 & 15.8 & 12.0 & 16.9 & 13.1 & 13.8 & 14.4 & 14.8 & 3.8 & 1.3 \\
\hline 2001 & 10.3 & 10.3 & 10.2 & 16.8 & 40.1 & 19.2 & 19.2 & 23.2 & 10.7 & 17.5 & 6.4 & 7.2 & 15.8 & 11.5 & 16.9 & 13.1 & 13.8 & 14.4 & 14.8 & 3.8 & 1.3 \\
\hline 2002 & 10.3 & 10.3 & 10.2 & 16.8 & 40.1 & 19.2 & 19.2 & 23.2 & 10.7 & 17.5 & 6.4 & 7.2 & 15.8 & 9.2 & 16.9 & 13.1 & 14.6 & 14.4 & 14.8 & 3.8 & 1.3 \\
\hline 2003 & 10.3 & 10.3 & 10.2 & 16.8 & 40.1 & 19.2 & 19.2 & 23.2 & 10.7 & 17.5 & 6.4 & 7.2 & 15.8 & 9.2 & 16.9 & 13.1 & 14.7 & 14.4 & 14.8 & 3.8 & 1.3 \\
\hline
\end{tabular}




\section{Selected Bibliography}

Addison, J. T., \& Grosso, J. (1993). Job security provisions and employment: revised estimates. Industrial Relations, 35(4), 585-603.

Algan, Y., Cahuc, P., \& Zylberberg, A. ( 2002). Public em ployment: does it increase unemployment? Economic Policy, 34, 41-46.

Bertola, G., \& Rogerson, R. (1997). Institutions and labor reallocation. European Economic Review, 41, 1147-1171.

Blanchard, O., \& W olfers, J. (2000). The role of shocks and institutions in the rise of European unemployment: the aggregate evidence. Economic Journal, 110, 1-33.

Boeri, T., (1999). Enforcem ent of employment security regulations, on-the-job search and unemployment duration. European Economic Review 43, 65-89.

Grubb, D., \& W ells, W. (1993). Em ployment regulation and patterns of work in EC countries. OECD Economic Studies, 21, 7-58.

Lazear, E. P. (1990). Job secur ity provisions and em ployment. Quarterly Journal of Economics, 105(3), 699-725.

Martin, J. P. (2000/1). W hat works am ong active labour market policies: evidence from OECD countries' experiences. OECD Economic Studies, 30.

Nickell, S. (1997). Unem ployment and labor market rigidities: Europe versus North America. Journal of Economic Perspectives, 11(3), 55-74.

OECD. (1994). THE OECD Jobs Study, 1994.

OECD. (1999). Employment protection and labour market performance (Employment Outlook chapter 2).

OECD. (2002). And the twain shall meet: cross-market effects of labour and product market policies (Employment Outlook chapter 5).

Scarpetta, S. (1996/1). Assessing the role of labour market policies and institutional settings on unemployment: a cross-country study. OECD Economic Studies, 26. 


\section{Notes}

${ }^{\mathrm{i}}$ The less educated are more likely to be unemployed: in terms of levels, the ratio of employment to population in selected OECD countries is higher for more educated workers; less educated were invariably more likely to be unemployed than the more educated; and the differences in unemployment associated with education tended to rise. Benefits redistribute incom e from the rich, higher-skilled or educat ed, to the poor, less educated. The unemployed are also less likely to find jobs as time goes on. See Richard B. Freem an, ed., Working Under Different Rules, 1994, p. 41.

ii In fact, the factor that was shown to have the most important impact on exit rates from unemployment in the Spanish and Portuguese case was whet her an individual received unem ployment benefits or not (see Olym pia Bover, Pilar García-Perea, Pedro Port ugal, "A C omparative Study of the Portuguese and Spani sh Labour Markets”, Estudos e Documentos de Trabalho, Banco de Portugal, March 1998, pp. 17-18).

iii Sveinbjorn Blondal and M ark Pearson, "Unem ployment and Other Non-Employment Benefits", Oxford Review of Economic Policy, vol. 11, no. 1, pp. 137-140.

${ }^{\text {iv }}$ Abbring, van den Berg and van Ours (2000).

${ }^{\mathrm{v}}$ Hunt (1995) finds very large effects of the level of potential duration of benefits in Germany.

${ }^{\mathrm{vi}}$ The em pirical hazard function (or exit rate from unemployment), which shows how the changes of reemployment change as the length of the unemployment spell progresses, can be shown to decline over time; in other words, they are non-constant and are said to exhibit duration dependence. There are reasons for this: first, skill depreciation during unem ployment makes the individual less employable; second, stigmatization of longterm unemployed by potential employers leads to decreasing arrival rates of job offers; third, discouragement lowers search intensity; and fourth, unobserved individual heterogeneity causes "spuri ous" negative duration dependence because in the presence of heterogenous individuals, the sample of those still unemployed is

vii Sveinbjorn Blondal and M ark Pearson, "Unem ployment and Other Non-Employment Benefits", Oxford Review of Economic Policy, vol. 11, no. 1, pp. 137-140. Outflow rates have been found to increase considerably at around the times the unemployment benefits are exhausted in the United States, Canada, Japan, France, Spain and Sweden, raising the possibility that maximum benefit periods influence the duration of unemployment spells. Also unemployment benefit recipients have been shown to move to employment at a significantly lower pace than non-recipients; in fact, the factor that was shown to have the most important impact on exit rates from unemployment in the Spanish and Portuguese case was whether an individual received unem ployment benefits or not (see Olympia Bover, Pilar García-Perea, Pedro Portugal, "A Comparative Study of the Portuguese and Spanish Labour Markets", Estudos e Documentos de Trabalho, Banco de Portugal, March 1998, pp. 17-18).

${ }^{\text {viii }}$ The United States, Canada, the United Kingdom, New Zealand and Ireland have all introduced measures to offset the distortionary effects of high marginal effective tax rates on low incomes, as benefits are phased out and income becomes subject to tax after a low income threshold has been passed. See Implementing the OECD Jobs Strategy: Member Countries' Experience, OECD, 1997, p. 63. There are al so numerous cases where payroll taxes have been rai sed to finance rising unemployment insurance costs. See, for instance, OECD Economic Surveys: Canada, 1996. There is evidence that the rate of increase in the tax rather than its overall level is the better indicator of potential harm to the labor market.

${ }^{i x}$ A. Lindbeck, "The Welfare State and the Employment Problem", American Economic Review 84 (2: 1994), p. 74.

${ }^{x}$ There are num erous cases where payroll taxes have $\mathrm{b}$ een raised to finance ri sing unemployment insurance costs. See, for instance, OECD Economic Surveys: Canada, 1996. There is evidence that the rate of increase in the tax rather than its overall level is the better indicator of potential harm to the labor market.

${ }^{x i}$ Layard (1988) sum marizes: "The correl ation of une mployment duration with unemployment benefits is predicted by almost every known model of unemployment." It should be noted that the strength of all of these disincentive effects depends on the eligibility criteria for benefits, wh ich make payment conditional upon job search and related behavior. These criteria can offset or even reverse the disincentiv e effects that arise when benefits are paid without these conditions; and at the aggregate level, the European countries where unemployment fell $\mathrm{m}$ ost sharply in the 1990s had tighten ed the im plementation of their benefit eligibility criteria. See OECD Employment Outlook 2000, p. 129 and rest of article. Note that the enforcement of eligibility criteria may have a larger im pact on behavior than vari ations in replacement rates and effective $\mathrm{m}$ arginal tax rates, because the incom e implications for the beneficiary are larger : ineligibility $m$ eans the replacement rate falls to zero. 
xii There are num erous cases where payroll taxes have $b$ een raised to finance ri sing unemployment insurance costs. See, for instance, OECD Economic Surveys: Canada, 1996. There is evidence that the rate of increase in the tax rather than its overall level is the better indicator of potential harm to the labor market.

xiii Sveinbjorn Blondal and M ark Pearson, "Unem ployment and Ot her Non-Employment Benefits", Oxford Review of Economic Policy, vol. 11, no. 1, p. 137.

xiv The OECD has calculated average gross replacement rates for odd-num bered years from 1961 on. Som e countries make available other benefits to the unemployed, which would raise the reservation wage further, and these are not included in the OECD figures. The Centraal Planbureau in The Hague has developed an index that uses net replacement rates plus housing and other benefits available for the unemployed in the European Union and three U.S. states, and this index gives a very different picture of the replacem ent rate; but this index was developed only for a single year, 1993, and would be too difficult to replicate in this study. However, it might be used for a "snapshot" comparison.

${ }^{\mathrm{xv}}$ OECD, Benefits and Wages: OECD Indicators, Paris 2002, p. 10.

${ }^{x v i}$ OECD, Benefits and Wages: OECD Indicators, Paris 2002, p. 33 gi ves examples for a si ngle year (1999). Data for net replacement rates can be obtained on line for 1997 and 1999.

xvii OECD, Benefits and Wages: OECD Indicators, Paris 2002, p. 12.

xviii Olympia Bover, Pilar García-Perea, Pedro Portugal, “A Comparative Study of the Portuguese and Spanish Labour Markets", Estudos e Documentos de Trabalho, Banco de Portugal, March 1998, pp. 16-18). See al so Sveinbjorn Blondal and Mark Pearson, "Unemployment and Other Non-Employment Benefits", Oxford Review of Economic Policy, vol. 11, no. 1, pp. 137-140. Outflow rates were found to increase considerably at around the times the unemployment benefits were ex hausted in the United States, Canada, Japan, France, Spai n and Sweden, raising the possibility that maximum benefit periods influence the duration of unemployment spells.

The empirical hazard function (or exit rate from unemployment), which shows how the changes of reemployment change as the length of the unemployment spell progresses, can be shown to decline over time; in other words, they are non-constant and are said to exhibit duration dependence. There are reasons for this: first, skill depreciation during unem ployment makes the individual less employable; second, stigmatization of longterm unemployed by potential employers leads to decreasing arrival rates of job offers; third, discouragement lowers search intensity; and fourth, unobserved individual heterogeneity causes "spuri ous" negative duration dependence because in the presence of heterogenous i ndividuals, the sam ple of those still unem ployed is increasingly made up of those workers with unobserved characteristics which make them less employable.

${ }^{x i x}$ In all of these respects, Norway is a model of all-round strictness: the unemployed must generally accept shift and night work, be prepared to work anywhere in Norway (and a spouse who qui ts a job to avoid separation of the couple and then claims benefit will be penalized for a voluntary quit), must be ready to accept any job they can do wi thout reference to their previous occupation or wage level, and cannot refuse a job on rel igious or ethical grounds. The Uni ted States, Australia, the Netherlands, Switzerland and the United Kingdom require individuals to report their job search i n some detail and specify a minimum frequency of job appl ications or actions of job search. In $t$ he United States, the unemployed in most states have to make two or more job applications every week. In France there is a principle of permanent job search and the unemployed are required to keep documentation and intensive reviews of job search are conducted at intervals of four months or more and are a prime instrument in verification of eligibility.

${ }^{\mathrm{xx}}$ Imagine that the unem ployed receive a series of job o ffers at different wage leve ls, and would reject those paying wages bel ow their "reservation wage". Pay ment of the benefit raises the reservation wage and coul d hence increase the expected duration of unemployment spells. But if the public employment service imposes strong sanctions, such as perm anent exclusion from the benefit system, if an offer pay ing a "suitable" wage is rejected, that "suitable wage" can be set below the reservation wage that unemployed people would choose in the absence of any benefit system. Unemployment spell durations should therefore be lower than under laissez faire. See Ljungqvist and Sargent, 1995.

${ }^{x x i}$ P. Auer, Employment Revival in Europe: Labour Market Success in Austria, Denmark, Ireland and the Netherlands, ILO, Geneva, 2000.

xxii Ministry of Finance, Denm ark, “Availability Criteria in Selected OECD Countries", Working Paper no. 6, November 1998.

xxiii Table 8.B.1., p. 226, The OECD Jobs Study: Evidence and Explanations. The y ears included are 1961, 1971, 1981 and 1991. 
${ }^{\text {xxiv }}$ This issue is a complex one, since tax is also applied to the average production wage, which the OECD uses as the denominator in its replacement rate, and different personal income tax rates apply to many of the different situations which the OECD estim ates in calculating its replacement rate. The OECD ratio, given for four different years, reflects the effect on both personal income tax and social security payments on wages and benefits. I have attempted to pinpoint when possible the year when changes in tax treatment took place, through my review of labor legislation and the literature.

${ }^{x x v}$ Since in $m$ ost EU countries unem ployment benefits can be received for an inde finite period, this does overlook an important aspect of the generosity of the unemployment insurance system: Lay ard, Nickell and Jackman (1991) show that economies respond well to exogenous shocks if they have an unemployment benefit system that discourages long-term unemployment, by which they mean a sy stem that offers unemployment benefits for a relatively short duration of 15 months or less; and Katz and Meyer (1990) concluded that in the United States, the length of the benefit period had a larger impact on the exit rate from unemployment than the benefit level. In this indicator, the value of 1 represen ts a duration of one y ear or more. However, the move from a fraction of a year to a year or more does represent an important change in the generosity of benefits.

${ }^{x}$ Initially the idea was to use a coverage rate as a proxy for the strictness of eligibility conditions for unemployment insurance. However, since this indicator did not appear to correlate well with the scores of the Danish study, and si nce developing the year-by-year, country-by-country EPL i ndicator described above involved a thorough review of labor-market legislation, I decided to attempt to develop an equal ly precise indicator for unemployment benefit eligibility.

${ }_{\text {xxvii }}$ Under Social Security Act of 1935, which created the system.

xxviii The Social Security Act (1935) also provides the basis for an unusual Federal state unemployment insurance system, under which the federal government establishes minimum guidelines and oversees the operation and performance of the system, while the states are free to enact their own laws as long as they comply with federal standards. See Flanagan, Robert J., "The United States: Decentralized Heterogeneity", Labour Market Contracts and Institutions, J. Hartog and J. Theeuwes, eds., Elsevier Science Publishers B.V., 1993, p. 39.

${ }^{\text {xxix }}$ According to Layard, et. al. (1991) under the income support scheme, all of an individual's rent (or his/her mortgage interest if a house owner) is also payable (unless the individual has savings of over 3,000 pounds; also account is taken of pension and/or redundancy payments). This obviously increases the replacement ratio. See also Joris Ghysels and Anne Thirion, Final Report to the European Commission under project number V/031/98 To Identify and Com pare Social Protection System Benefits and Repl acement Rates and Their Effect on Employment Participation in the Light of the 1998 Employment guidelines, 23 April 1999.

${ }_{\mathrm{xxx}}$ The first case is for a one-earner coupl e with two children and the second for a si ngle person. It should be noted that the OECD averages out 18 different situations in its replacement rate, as discussed above.

${ }^{x x x i}$ Centraal Planbureau, "Replacement rates: A transla tlantic view", W orking paper no. 80 (Septem ber 1995), The Hague.

xxxii Myd ecision followed the OECD's lead: the OECD also includes only the income available from unemployment insurance schemes in its replacement rates, partly because the other income support systems are so varied and com plex, but also because $\mathrm{m}$ any of them are means-tested and ther efore cannot be considered "insurance".

xxxiii The CIG, an extraordinary insurance benefit that applies in industrial sectors, offers a special unemployment allowance equal to two-thirds of the last daily earnings paid for 180 day s, when unem ployment is due to redundancy because of cessation of the ente rprise or of reduction in staff. It gives cost flexibility to em ployers but also freezes a sizeable fraction of the industrial labor force in inactive situati ons; beneficiaries reportedly work in huge numbers on the black market. CIG benefits and the Mobility allowance are paid only when the firm applies for these benefits in connection with a collective layoff. The CIG was much expanded in the 1970s. The CIGS was introduced in 1968, payable in cases of i ndustry-wide or local economy crises or restructuring of production. This made it possible to pay CIG during long-term layoffs. Legislation in 1977 clarified the principle that CIGS could, in socially relevant cases, be paid even when there was no expectation that the firm 's business might recover. Special arrangements were introduced for the INPS to pay benefits directly to workers instead of employers, in cases where the com pany formally employing them had effectively ceased to exist. In the 1980s there were $m$ any cases of workers receiving CIG for five years or $m$ ore. Law 223/1991 replaced Special Unemployment Benefits with a new Mobility allowance, initially paid at the same rate as CIG and reduced by $20 \%$ after one year. Firm s must pay into INPS the equivalent of $6 \mathrm{~m}$ onths of benefit for each worker put into Mobility. (Source: various OECD reports) 